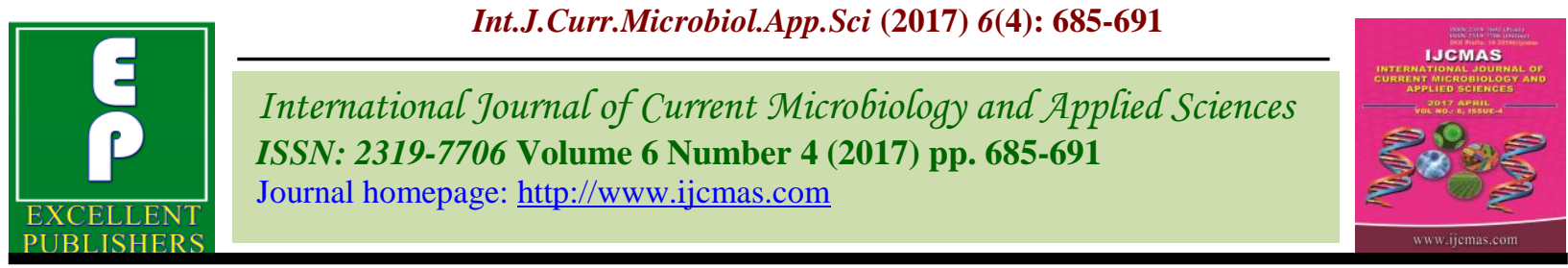

Original Research Article

https://doi.org/10.20546/ijcmas.2017.604.084

\title{
Phenology and Heat Unit Requirement of Summer Green Gram Varieties under Different Sowing Windows
}

\author{
Bharti Tijare, Anita Chorey*, Vilas Bhale and Sanjay Kakde
}

Department of Agronomy, Dr. Panjabrao Deshmukh Krishi Vidyapeeth,

Akola-444104 (M.S.), India

*Corresponding author

\section{A B S T R A C T}

\begin{tabular}{|l|}
\hline Ke y w o r d s \\
Green gram, \\
Growing degree \\
day, Phenology, \\
Sowing dates and \\
varieties.
\end{tabular}

A field experiment was conducted at the Agronomy Department farm, Dr. PDKV, Akola during summer season 2011 to study the phenology and heat unit requirement of summer green gram varieties grown under different sowing dates. As early sowing faces low temperature while late sowing faces high temperature during initial stage in Akola. The crop sown early ( $1^{\text {st }}$ march) took 73 days from sowing to maturity. While late sown green gram $\left(30^{\text {th }}\right.$ March) took 67 days for physiological maturity. Sowing on $30^{\text {th }}$ March accumulated significantly higher GDD, HTU and PTU at harvest $\left(1549.61{ }^{\mathrm{O}} \mathrm{C}\right.$ day, $12109.40{ }^{\mathrm{O}} \mathrm{C}$ day hour and $20609.8{ }^{\circ} \mathrm{C}$ day hour, respectively) as compared to rest of sowing dates from anthesis to physiological maturity. In case of varieties, PKV-Green gold accumulated significantly higher GDD, HTU and PTU at harvest $\left(1593.91{ }^{\mathrm{O}} \mathrm{C}\right.$ day, $12457.62{ }^{\circ} \mathrm{C}$ day hour and $20960.9^{\circ} \mathrm{C}$ day hour, respectively) followed by variety PKVAKM-04, whereas Pusa Vaishakhi recorded lowest values at all growth stages of crop. Sowing on $20^{\text {th }}$ March recorded significantly higher HUE and PUE for grain and biomass due to optimum temperature throughout the growth period. In respect of varieties HUE and PUE were higher in Pusa Vaishakhi viz; $0.738 \mathrm{~kg} \mathrm{ha}^{-1}{ }^{\mathrm{O}} \mathrm{C}$ day ${ }^{-1}$ and $0.056 \mathrm{~kg} \mathrm{ha}^{-1}{ }^{\mathrm{O}} \mathrm{C}$ day ${ }^{-1}$ for grain and $2.15 \mathrm{~kg} \mathrm{ha}^{-1}{ }^{\mathrm{O}} \mathrm{C}$ day $^{-1}$ and $0.164 \mathrm{~kg} \mathrm{ha}^{-1}{ }^{\mathrm{O}} \mathrm{C}$ day $^{-1}$ for biomass.

\section{Introduction}

Green gram (Vigna radiata L.) is third most important pulse crops in India. Being a leguminious, it is capable of meeting its nitrogen requirements from the atmospheric nitrogen through root nodules bacteria and also used as green manuring crop thus build up the soil fertility. The cultivation of Green gram during summer is becoming popular with the advent of high yielding, short duration and photo insensitive genotypes. These genotypes can express their full potential only when grown under optimum weather conditions. The time of sowing is an important non-monetary input to achieve synchronous maturity and higher productivity of summer green gram. As early sowing faces low temperature while late sowing faces high temperature during initial stage in Akola, these adversely affect the crop growth and yield. Therefore, determination of date of sowing and variety is important.

Plant has a definite temperature requirement before they attain certain phonological stages. A change in optimum temperature during different phonological stages of a crop 
adversely affects the initiation and duration of different phenophases and finally economic yield of the crop. It is therefore indispensable to haves knowledge of exact duration of phenophases in a particular environment and their association with yield attributes for achieving high yields (Kumari et al., 2009). Influence of temperature on phenology and yield of crop plan can be studied under field condition through accumulated heat unit system (Haider et al., 2003 and Pandey et al., 2010). Shift in sowing dates directly influence both thermo and photoperiod and consequently a great bearing on the phasic development and partitioning of dry matter (Leela Rani et al., 2012).

\section{Materials and Methods}

Field experiment was conducted during summer season 2011 at Agronomy Department farm, Dr. Panjabrao Deshmukh Krishi Vidyapeeth, Akola, having $22.42^{\circ} \mathrm{N}$ latitude, $77.02^{\circ} \mathrm{E}$ longitude and $307.4 \mathrm{M}$ above mean sea level. The soil of the experimental site was clay loam in texture, having $\mathrm{pH} 7.96$, Electrical conductivity 0.37 $\mathrm{dsm}^{-1}$, medium in Organic carbon, low in available nitrogen, medium in available phosphorus, and rich in available potassium. The treatment consisted of four sowing dates viz., $1^{\text {st }}$ March, 10 ${ }^{\text {th }}$ March, 20 ${ }^{\text {th }}$ March and $30^{\text {th }}$ March and three varieties viz., PKVAKM-04, PKV- Green gold and Pusa vaishakhi. The experiment was laid out in spilt plot design with three replications. The crop was fertilized with uniform dose of 20 $\mathrm{kg} \mathrm{ha}{ }^{-1} \mathrm{~N}$ and $40 \mathrm{~kg} \mathrm{ha}^{-1} \mathrm{P}_{2} \mathrm{O}_{5}$ through urea and single super phosphate, respectively at sowing time.

During the crop period mean maximum temperature varied from $33.5^{\circ} \mathrm{C}$ to $43.4^{0} \mathrm{C}$ and mean minimum temperature varied from $15.3^{\circ} \mathrm{C}$ to $28.7^{\circ} \mathrm{C}$. It indicated that mean minimum temperature ranges did not cross extreme high and extreme low temperature. The relative humidity at morning (RHI) varied from 34 to 68 percent, where it was 14 to 29 percent in evening (RHII). The bright sunshine hours (BHS) varied from 6.3 to 8.7. The wind velocity ranges from 1.9 to 12.9 $\mathrm{km} / \mathrm{hrs}$ during the growing season. The pan evaporation ranges from 6.7 to $17.3 \mathrm{~mm}$.

Accumulated agrometerological indices viz., GDD, HTU, PTU, HUE and PUE were computed by using daily meteorological data the date of occurrence of different phonological events viz., vegetative, anthesis, first pod and maturity were recorded when 75 percentage of the plants in each replicated reached the respective stages. GDD determine using base temperature of $10^{\circ} \mathrm{C}$ for summer green gram.

Growing degree days ( ${ }^{\mathrm{O}} \mathrm{C}$ day)

$\mathrm{GDD}=\frac{T \max +T \min }{2}-\mathrm{Tbase}$

Where,

$\mathrm{T}$ max $=$ Daily maximum temperature $\left({ }^{\circ} \mathrm{C}\right)$

$\mathrm{T}$ min $=$ Daily minimum temperature $\left({ }^{\circ} \mathrm{C}\right)$

$\mathrm{T}$ base $=$ Base temperature of $10^{\circ} \mathrm{C}$

Heliothermal unit $(\mathrm{HTU})=$ GDD $X$ Actual sunshine how

Photothermal unit $(\mathrm{PTU})=$ GDD $X$ Day length

$\operatorname{HUE}\left(\mathrm{kg} / \mathrm{ha} /{ }^{\circ} \mathrm{C}\right.$ day $)=$

Seed yield / Total dry matter ( $\mathrm{kg} / \mathrm{ha})$

Accumulated heat units $\left({ }^{\circ} \mathrm{C}\right.$ day $)$

$\operatorname{PUE}\left(\mathrm{kg} / \mathrm{ha} /{ }^{\circ} \mathrm{C}\right.$ day $)=$

Seed yield / Total dry matter (kg/ha)

Accumulated photothermal units $\left({ }^{\circ} \mathrm{C}\right.$ day $)$ 


\section{Results and Discussion}

Day's requirement for phenophases development

The day's requirement of phenophases development of summer green gram is presented in table 1. The number of days required to attain different phonological stages decreased with delay in sowing from $1^{\text {st }}$ March to $30^{\text {th }}$ March. The crop sown early $\left(1^{\text {st }}\right.$ march) took 73 days from sowing to maturity. While late sown green gram $\left(30^{\text {th }}\right.$ March) took 67 days for physiological maturity. For emergence, crop sown on $1^{\text {st }}$ March took significantly higher number of days as compared to other date of sowing (Table 1) due to low temperature during early growth period. The number of days taken from sowing to maturity was highest in early sown crop and decreased consistently with subsequent sowing, similar results was recorded by Kumar et al., (2012). In case of varieties PKV-Greengold took 73 days to attained maturity followed by variety PKVAKM-04 (69.50 days), whereas Pusa Vaishakhi required 67.50 days.

\section{Growing degree days (GDD)}

Accumulated thermal units presented in table 1 and revealed that GDD required for different phenophases varied with date of sowing. GDD were found to be significant at all the growth stages in different sowing dates and varieties. Significantly higher GDD from emergence to vegetative were recorded with $10^{\text {th }}$ March sowing.

Thereafter, from anthesis to physiological maturity sowing on $30^{\text {th }}$ March accumulated significantly higher GDD as compared to rest of the sowing dates. The accumulated GDD from sowing to physiological maturity ranged from 380.57 to 1496.13 degree days. Sowing on $30^{\text {th }}$ March accumulated significantly higher GDD at harvest (1549.61 OC day) as compared to $10^{\text {th }}$ March sowing (1502.12OC day), whereas lowest were accumulated in $1^{\text {st }}$ March sowing (1496.13 OC day) and significantly at par with $20^{\text {th }}$ March sowing (1535.61 OC day). GDD required from anthesis to maturity increases with delayed sowing. The requirement of GDD was higher for normal growing condition than early growing condition.

This was due to fluctuated unfavourable low temperature during growing period so, the requirement of heat units decreased for different phonological stages with early sowing. Air temperature based agromet indice GDD has been used to describe changes in phonological behavior and growth parameters (Dhaliwal et al., 2007; Singh et al., 2007 and Kumar et al., 2008).

Amongst all varieties, PKV-Green gold observed statistically higher GDD from emergence to maturity. Variety PKV-Green gold accumulated significantly higher GDD at harvest (1593.910C day) followed by variety PKV-AKM-04 (1508.94OC day), whereas lowest accumulated GDD (1459.45 OC day) was recorded for variety Pusa Vaishakhi. Early development of phonological stages might be the reason for less consumption of heat unit (Pandey et al., 2010).

\section{Heliothermal units (HTU)}

The heliothermal unit requirements for entire growth phases were found to decrease with delay sown crop and showed higher consumption of HTU as compared to early sown crop (Table 1). Late sown crop absorbed sufficient GDD in relative less time due to prevalence of higher temperature and longer sunshine hour during post sowing period (Pandey et al., 2010). 
Table.1 Agrometeorological indices during different growth stages of summer green gram varieties under different sowing windows

\begin{tabular}{|c|c|c|c|c|c|c|c|c|c|c|c|c|c|c|c|c|}
\hline \multirow{2}{*}{ Treatments } & \multicolumn{4}{|c|}{ Emergence to vegetative } & \multicolumn{4}{|c|}{ Emergence to Anthesis } & \multicolumn{4}{|c|}{ Emergence to First pod } & \multicolumn{4}{|c|}{$\begin{array}{c}\text { Emergence to Physiological } \\
\text { maturity }\end{array}$} \\
\hline & $\begin{array}{l}\text { Days } \\
\text { taken }\end{array}$ & GDD & HTU & PTU & $\begin{array}{l}\text { Days } \\
\text { taken }\end{array}$ & GDD & HTU & PTU & $\begin{array}{l}\text { Days } \\
\text { taken }\end{array}$ & GDD & HTU & PTU & $\begin{array}{l}\text { Days } \\
\text { taken }\end{array}$ & GDD & HTU & PTU \\
\hline \multicolumn{17}{|c|}{ Sowing dates } \\
\hline $\begin{array}{l}S_{1^{-}} 1^{\text {st }} \\
\text { March }\end{array}$ & 22.33 & 391.32 & 2919.56 & 4695.87 & 33.66 & 613.60 & 4719.20 & $|7731.36|$ & 41.00 & 757.61 & 5734.37 & 9545.97 & 73.00 & 1496.13 & 11545.80 & 19599.3 \\
\hline $\begin{array}{l}\mathrm{S}_{2-} \mathbf{1 0}^{\text {th }} \\
\text { March }\end{array}$ & 21.00 & 80.87 & 3109.26 & 4568.13 & 32.66 & 611.55 & 4840.87 & 7705.53 & 40.33 & 783.51 & 6128.46 & 9872.24 & 70.66 & 1502.12 & 11933.50 & 19677.8 \\
\hline $\begin{array}{l}\mathrm{S}_{3^{-}} \mathbf{2 0}^{\text {th }} \\
\text { March }\end{array}$ & 19.66 & 89.20 & 3054.92 & 4903.99 & 31.33 & 619.51 & 4745.57 & 7805.84 & 38.66 & 779.95 & 5984.37 & 9827.44 & 69.33 & 1535.21 & 12065.20 & 20111.3 \\
\hline $\begin{array}{l}\mathrm{S}_{4}-\mathbf{3 0}^{\text {th }} \\
\text { March }\end{array}$ & 18.66 & 384.55 & 2902.83 & 4845.40 & 30.33 & 643.10 & 4893.97 & 8143.68 & 37.66 & 819.76 & 6259.72 & 10738.9 & 67.00 & $1549.61 \mid$ & 12109.40 & 20609.8 \\
\hline $\mathrm{SE}(\mathrm{m}) \pm$ & 34 & 6.83 & 58.00 & 82.12 & 0.60 & 13.07 & & 170.47 & 0.44 & 10.18 & 87.51 & & 0.24 & 6.17 & 52.32 & 80.78 \\
\hline & 20 & 4.10 & 204.70 & 284.19 & 2.10 & 46.12 & 367.01 & 589.94 & 1.55 & 35.23 & .86 & & 0.83 & 21.35 & 181.06 & 279.56 \\
\hline \multicolumn{17}{|c|}{ Varieties } \\
\hline $\begin{array}{l}\text { V }- \text { PKV- } \\
\text { AKM-04 }\end{array}$ & 20.50 & 388.11 & 3012.57 & 4775.47 & 32.50 & 632.70 & 4892.33 & 7972.07 & 39.50 & 786.11 & 6026.60 & 10005.5 & 69.50 & 1508.94 & 11834.50 & 19843.5 \\
\hline $\begin{array}{l}V_{2} \text {-PKV- } \\
\text { Green gold }\end{array}$ & 21.75 & 413.89 & 3200.16 & 5091.22 & 33.50 & 655.03 & 5060.50 & 8283.88 & 41.25 & 826.45 & 6362.61 & 10522.9 & 73.00 & 1593.91 & 12464.40 & 20960.9 \\
\hline $\begin{array}{l}V_{3} \text {-Pusa } \\
\text { Vaishakhi }\end{array}$ & 19.00 & 357.30 & 2777.20 & $4393.36 \mid$ & 30.00 & 578.08 & 4448.11 & 7283.85 & 37.50 & 743.06 & 5690.98 & 9460.02 & 67.50 & 1459.45 & 11441.60 & 19194.1 \\
\hline & 0.45 & & 68.71 & 113.02 & 0.36 & 8.20 & & 112.10 & 0.44 & 9.88 & 77.38 & 124.74 & 0.37 & 9.24 & 72.71 & 121.41 \\
\hline CD at $5 \%$ & 1.35 & 27.55 & 206.01 & 338.86 & 1.08 & 24.61 & 184.18 & 336.10 & 1.33 & 29.62 & 232.02 & 374.00 & 1.11 & 27.71 & 218.01 & 364.00 \\
\hline
\end{tabular}


Table.2 Efficiency indices at physiological maturity in summer green gram varieties under different sowing windows

\begin{tabular}{|c|c|c|c|c|c|c|}
\hline \multirow[t]{2}{*}{ Treatments } & \multirow[t]{2}{*}{$\begin{array}{l}\text { Biomass } \\
\left(\mathrm{kg} \mathrm{ha}^{-1}\right)\end{array}$} & \multirow[t]{2}{*}{$\begin{array}{c}\text { Grain } \\
\text { yield } \\
\left(\mathrm{kg} \mathrm{ha}^{-1}\right)\end{array}$} & \multicolumn{2}{|c|}{$\begin{array}{l}\text { Heat use efficiency } \\
\left(\mathrm{kg} \mathrm{ha}^{-1}{ }^{\mathrm{O}} \mathrm{C} \mathrm{day}^{-1}\right)\end{array}$} & \multicolumn{2}{|c|}{$\begin{array}{c}\text { Photothermal use } \\
\text { efficiency } \\
\left(\mathrm{kg} \mathrm{ha}^{-1}{ }^{\mathbf{O}} \mathrm{C} \text { day }^{-1}\right)\end{array}$} \\
\hline & & & Biomass & Grain & Biomass & Grain \\
\hline \multicolumn{7}{|l|}{ Sowing dates } \\
\hline$S_{1}-1^{\text {st }}$ March & 2746.53 & 829.11 & 1.84 & 0.557 & 0.140 & 0.042 \\
\hline$S_{2-} 10^{\text {th }}$ March & 2865.11 & 906.16 & 1.91 & 0.607 & 0.146 & 0.046 \\
\hline $\mathrm{S}_{3^{-}}$20 $^{\text {th }}$ March & 3139.42 & 1086.5 & 2.05 & 0.710 & 0.156 & 0.054 \\
\hline $\mathrm{S}_{4}-\mathbf{3 0}^{\text {th }}$ March & 2989.18 & 992.87 & 1.93 & 0.643 & 0.145 & 0.048 \\
\hline $\mathrm{SE}(\mathrm{m}) \pm$ & 78.21 & 28.76 & 0.03 & 0.02 & 0.002 & 0.001 \\
\hline CD at $5 \%$ & 270.60 & 99.55 & 0.13 & 0.07 & 0.010 & 0.005 \\
\hline \multicolumn{7}{|l|}{ Varieties } \\
\hline $\mathrm{V}_{1}$ - PKV-AKM-04 & 2887.53 & 941.30 & 1.91 & 0.623 & 0.145 & 0.047 \\
\hline $\mathrm{V}_{2}$-PKV-Green gold & 2766.08 & 841.08 & 1.73 & 0.527 & 0.131 & 0.040 \\
\hline V $_{3}$-Pusa Vaishakhi & 3151.57 & 1078.6 & 2.15 & 0.738 & 0.164 & 0.056 \\
\hline $\mathrm{SE}(\mathbf{m}) \pm$ & 72.06 & 23.50 & 0.02 & 0.02 & 0.002 & 0.001 \\
\hline CD at $5 \%$ & 215.85 & 70.46 & 0.08 & 0.06 & 0.006 & 0.003 \\
\hline
\end{tabular}

At emergence to vegetative stage $10^{\text {th }}$ March sowing accumulated significantly higher HTU (3109.26 OC day hour) and was comparable with $20^{\text {th }}$ March (3054.92 OC day hour) and $1^{\text {st }}$ March (2919.87 OC day hour) whereas significantly lower with $30^{\text {th }}$ March sowing (2902.830C day hour). However, from anthesis to maturity crop sown on $30^{\text {th }}$ March accumulated significantly higher HTU (12109.40 OC day hour) and was comparable with crop sown on $20^{\text {th }}$ March (12065.20 OC day hour) and10 ${ }^{\text {th }}$ March (11933.50 OC day hour) whereas, sowing on 1st March recorded lowest HTU (11545.80 OC day hour).

In respect of varieties, statistically higher HTU were accumulated with PKV- green gold at all the growth stages of crop. Similarly, at physiological maturity stage, among varieties pusa vaishakhi (11441.60 OC day hour) and PKV- AKM-04 (11834.50 OC day hour) acquired significantly less HTU than PKV- green gold (12464.40 OC day hour). It might be due to their longer life cycle than other varieties (Ram et al., 2012).

\section{Photothermal unit (PTU)}

The photothermal unit for different phenophases presented in table 1 indicated that PTU requirement for entire growth phase increase as the sowing was delayed up to $30^{\text {th }}$ March and thereafter it decreases up to $1^{\text {st }}$ March. This may be due to shorter day length, low temperature during early vegetative phase and longer day length, high temperature during late development phase (Kumar et al., 2010). The crop sown on $30^{\text {th }}$ March required more PTU due to longer day length, PTU during 100 percent anthesis to first pod thereafter decreases with short day length.

Accumulation of photothernal unit (PTU) at emergence to vegetative growth stage found significantly higher in $20^{\text {th }}$ March sowing (4903.990C day hour). However, from 
anthesis to physiological maturity accumulation PTU among $30^{\text {th }}$ March sowing (20609.8OC day hour) which was significantly higher than $20^{\text {th }}$ March (20111.3OC day hour), $10^{\text {th }}$ March (19677.8OC day hour) and $1^{\text {st }}$ March (19599.3OC day hour) sown crop.

Amongst all varieties, from sowing to maturity PKV- green gold accumulated significantly higher PTU at harvest (20960.9 OC day hour) while lowest values were recorded with PKV-AKM-04 (19843.5OC day hour) and Pusa Vaishakhi (19194.1OC day hour)

\section{Heat and photothermal use efficiency (HUE and PUE)}

Sowing on $20^{\text {th }}$ March showed higher HUE of $0.710 \mathrm{~kg} \mathrm{ha}^{-1} \mathrm{OC}$ day $^{-1}$ for grain and $2.05 \mathrm{~kg}$ $\mathrm{ha}^{-1}$ OC day $^{-1}$ for biomass and was statistically at par with $30^{\text {th }}$ March with 0.643 $\mathrm{kg} \mathrm{ha}^{-1} \mathrm{OC}$ day $^{-1}$ for grain and $1.93 \mathrm{~kg} \mathrm{ha}^{-1}$ OC day $^{-1}$ for biomass (Table 2), whereas, it was significantly lowest with $1^{\text {st }}$ March sowing $\left(0.557 \mathrm{~kg} \mathrm{ha}^{-1} \mathrm{OC}\right.$ day $^{-1}$ for grain and $1.84 \mathrm{~kg} \mathrm{ha}^{-1}$ OC day ${ }^{-1}$ for biomass). Similar trend was observed for PUE. Sowing on $20^{\text {th }}$ March acquired higher PUE of $0.042 \mathrm{~kg} \mathrm{ha}^{-1}$ OC day ${ }^{-1}$ for grain and $0.140 \mathrm{~kg} \mathrm{ha}^{-1} \mathrm{OC}$ day ${ }^{1}$ for biomass whereas lowest PUE recorded with sowing on $1^{\text {st }}$ March $\left(0.054 \mathrm{~kg} \mathrm{ha}^{-1} \mathrm{OC}\right.$ day $^{-1}$ for grain and $0.156 \mathrm{~kg} \mathrm{ha}^{-1} \mathrm{OC}$ day $^{-1}$ for biomass). The heat and photothermal use efficiency were decreased with early sowing. Higher HUE and PUE with $20^{\text {th }}$ March sown crop could be attributed to higher grain and biomass yield. As temperature was optimum throughout the growing period the crop utilized heat efficiently and increased biological activity that confirms higher yield. Similar relationship was also expressed by, Thavaprakash et al., (2007). In case of varieties, HUE and PUE were significantly higher in Pusa Vaishakhi $0.738 \mathrm{~kg} \mathrm{ha}^{-1}$ OC day $_{-1}$ and $0.056 \mathrm{~kg} \mathrm{ha}^{-1} \mathrm{OC}$ day $^{-1}$ for grain and $2.15 \mathrm{~kg} \mathrm{ha}^{-1} \mathrm{OC}_{\mathrm{day}^{-1}}$ and $0.164 \mathrm{~kg} \mathrm{ha}^{-1}$ OC day $^{-1}$ for biomass, respectively, as compared to that in PKV-AKM-04 with $0.623 \mathrm{~kg} \mathrm{ha}^{-1}$ OC day ${ }^{-1}$ and $0.047 \mathrm{~kg} \mathrm{ha}^{-1}$ OC day ${ }^{-1}$ for grain and $1.91 \mathrm{~kg} \mathrm{ha}^{-1} \mathrm{OC}$ day $^{-1}$ and $0.145 \mathrm{~kg} \mathrm{ha}^{-1}$ OC day $^{-1}$ for biomass and lowest in PKVgreen gold $\left(0.527 \mathrm{~kg} \mathrm{ha}^{-1} \mathrm{OC}\right.$ day $^{-1}$ and 0.040 $\mathrm{kg} \mathrm{ha}^{-1} \mathrm{OC}$ day $^{-1}$ for grain and $1.73 \mathrm{~kg} \mathrm{ha}^{-1}$ OC day $^{-1}$ and $0.131 \mathrm{~kg} \mathrm{ha}^{-1}$ OC day $^{-1}$ for biomass). Higher HUE and PUE in Pusa Vaishakhi variety could be attributed to higher grain and biomass yield.

In conclusion the crop sown on $1^{\text {st }}$ March took maximum calendar days. Growing degree days, heliothermal units and photothermal units form emergence to physiological maturity which got increase with subsequent delay in sowing time recorded highest value on 30th March sown crop. Sowing on $20^{\text {th }}$ March recorded significantly highest grain yield, biomass yield, heat use efficiency and photothermal use efficiency as compared to rest of sowing dates. Among varieties PKV- green gold took the highest calendar days, growing degree days, heliothermal units and photothermal units from emergence to physiological maturity. In case of grain yield, biomass yield, heat use efficiency and photothermal use efficiency, pusa vaishakhi recored significantly higher values as compared to other varieties.

\section{References}

Dhaliwal, L.K., Hundal, S.S., Kular, J.S., Aneja, A. and Chahal S.K. 2007. Accumulated heat units requirements for different phenophases of raya (Brassica juncea L.) as influenced by sowing dates. Ind. J. Crop Sci., 2: 103105.

Haider, S.A., Alam, M.Z., Alma, M.F. and Paul, N.K. 2003. Influence of different 
sowing dates on the phenology and accumulated heat units in wheat. J. Biol. Sci., 3: 932-939.

Kumar, A., Pandey, V., Shekh, A.M. and Kumar, M. 2008. Growth and yield response of soybean (Glycine max L.) in relation to temperature, photoperiod and sunshine duration at Anand, Gujarat, India. American-Eurasian J. Agron., 1(2): 45-50.

Kumar, P., Wadwood, A., Singh, R.S. and Kumar, R. 2009. Response of wheat crop to different thermal regimes under agroclimatic conditions of Jharkhand. $J$. Agrometerol., 11(1): 133-136.

Kumar, R., Kundal, M., Vats, S.K. and Kumar, S. 2012. Agrometerological indices of white clover (Trifolium repens) in western Himalayas. $J$. Agrometerol., 14(2): 138-142.

Leela Rani, Sreenivas, G. and Reddy, D.R. 2012. Thermal time requirement and energy use efficiency for single cross hybrid maize in south telangana agro climatic zone of Andhra Pradesh. $J$.
Agrometerol., 14(2): 143-146.

Pandey, I.B., Pandey, R.K., Dwivedi, D.K. and Singh, R.S. 2010. Phenology, heat unit requirement and yield of wheat (Triticum aestivum) varieties under crop growing environment. Ind. J. Agric. Sci., 80(2): 136-140.

Ram, H., Snigh, G., Mavi, G.S. and Sohu, V.S. 2012. Accumulated heat unit requirement and yield of irrigated wheat (Triticum aestivum L.) varieties under different crop growing environment in central Punjab. J. Agrometerol., 14(2): 147-153.

Singh, A., Rao, V.U.M., Singh, D. and Singh, R. 2007. Study on agrometerological indices for soybean crop under different growing environments. J. Agrometerol., 9: $81-85$.

Thavaprakash, N., Jagannathan, R., Velayudham, K. and Gurusamy, L. 2007. Seasonal influence on phenology and accumulated heat units in relation to yield of baby corn. Intern. J. Agric. Res., 2(9): 826-831.

\section{How to cite this article:}

Bharti Tijare, Anita Chorey, Vilas Bhale and Sanjay Kakde. 2017. Phenology and Heat Unit Requirement of Summer Green Gram Varieties under Different Sowing Windows. Int.J.Curr.Microbiol.App.Sci. 6(4): 685-691. doi: https://doi.org/10.20546/ijcmas.2017.604.084 